\title{
Aqui, agora: poder e mito
}

O PRESENTE ENSAIO reunirá algumas evidências sobre o telejornal Aqui, Agora, do Sistema Brasileiro de Televisão (SBT). Elas emergiram de uma pesquisa semiológica, realizada em nove edições, de 1997, fixada na produção de sentido. Foi usado o paradigma de Barthes, sobretudo, através das categorias Fait Divers, Poder e Mito, voltadas para a tipologia informativa e para a organização de cada edição.

As nove edições do telejornal, de 29, 30 e 31 de julho e $1^{\circ}, 04,05,11,12$ e 18 de agosto, de 1997, somaram 59 telerrepor-tagens. Todas foram tipificadas como Fait Divers, em suas várias expressões, que determinaram, também, a lógica de organização de cada edição.

O montante teve 52 Fait Divers de Coincidência - 48 de Antítese e quatro de Repetição - e sete de Causalidade de Causa Perturbada, quanto à tipologia informativa. $\mathrm{O}$ de Coincidência foi, ainda, hegemônico em relação à organização das edições.

Constatou-se que a disposição das matérias não foi aleatória. Obedeceu à lógica do Fait Divers de Coincidência. A seqüência delas foi estabelecida por Antíteses, ora trágicas, ora de final feliz, individualmente ou em blocos, reiteradas pela Repetição.

Roberto Ramos

Dr. Educação - PUCRS

Prof. do Programa de Pós-grad. da FAMECOS/PUCRS

\section{Fait Divers}

Cabe, no compasso da brevidade, recuperar a teorização do Fait Divers, traçada por Barthes (1971: 263). Ele o caracteriza como "a informação monstruosa, análoga a todos os fatos excepcionais ou insignificantes, em resumo anônimos".

A eleição da palavra "monstruosa" não foi um voto aleatório. Possui um sentido sumariante. Ela dispõe de uma polissemia admirável - anômalo, descomunal, grotesca, inusitada, hedionda, incrível, entre outras - especificante da categorização do Fait Divers. 
A síntese, enlaçada na palavra "anônimos", é antecedida pela relativização, delineada por "análoga", que prescreve o horizonte dialético. O Fait Divers se expressa pelas factualidades, anônimas, mas, também, pelas factualidades notórias. Ambas se encontram monitoradas, em suas particularidades, pela monstruosidade, que, na sua polissemia, singulariza a noção de conflito.

O semiólogo (1971) ultrapassou as fronteiras da conceituação. Vestiu o Fait Divers de uma categorização, alinhavada por dois tipos básicos e seus respectivos subtipos: Causalidade - Causa Perturbada e Causa Esperada - e Coincidência - Repetição e Antítese.

Em suas diversas manifestações, o Fait Divers estabelece conflitos, fixados nas paredes do presente. É, por excelência, narcísico, preso ao continente de suas experiências. Interpela pela isca da emocio-nalidade. Em seu circuito imanente, não há tempo para a razão e para as lentes intelectuais, o imediatismo do seu consumo emocional recorre à Fatalidade. Ela é o seu Sujeito Absoluto, sua tábua metafísica, de espessura ahistórica, para explicar a confli-tuosidade histórica. É o sincretismo de seu estilo barroco.

No seu esboço imanente, forjado pelo narcisismo e pela emocionalidade, o Fait Divers mostra os conflitos históricos, mas os demonstra por um espelho único: a Fatalidade, em seu espectro ahistórico, apaziguante da conflituosidade histórica.

Os 59 Fait Divers, que habitaram o altiplano das nove edições do Aqui, Agora, denotaram um mosaico de violência na territorialidade urbana. Ela exibiu a face única de sua expressividade física, com os rabiscos, multifacetados, pelo roubo, ferimento, estupro, incêndio e pelo crime.

Verificou-se que o Fait Divers, em seus tipos e subtipos, foi o Significante inva-riante da linguagem das nove edições do telejornal. Ele denotou conflitos, materializados pela violência física, em sua polis-semia, explicada pela Fatalidade, como determinante histórico.

Constituiu-se, por conseguinte, o
Sistema de Significação do Aqui, Agora. O Significante foi o Fait Divers, o Significado, os conflitos, como expressão de violência física, ambos instaurando o Signo. Tal trinômio realizou o Sistema de Significação, primário, denotativo.

O Poder (Libido dominante), como anota Barthes (s.d.) está associado, ainda que ele não associe, ao Sistema de Significação, primário, denotativo. Relaciona-se com o Significado - violência física, em suas múltiplas traduções, decodificadas pela Fatalidade.

Vale sublinhar que o Significado é da ordem da consciência, absolutizada pela sociedade burguesa. A sua sacralização, como reduto ímpar da vontade humana, fonte, sem par, geradora da ação humana, representou toda a condição da dominação ideológica.

O Significado - violência física - foi exibido na vitrine eletrônica, porém foi iluminado pelos spots da Fatalidade, sua suprema e única explicação. Retirou-lhe o contexto histórico; concedeu-lhe o contexto ahistórico.

Repetiu-se, nesse sentido, um aspecto estrutural da Tragédia grega. Nela, os impasses históricos, quando incontornáveis encontravam os seus contornos na ahistori-cidade, com a presença de um Deus-exMachina, saído do Olimpo, supremo Pai, Sujeito Absoluto por excelência.

O Poder está conectado com a Fatalidade, o Deus-ex-Machina. Tal relação se localiza na clarividência natural, própria da denotação. É uma questão que reside no Sistema de Significação, primário, denotado.

A categoria Poder é importante. Possui a sua angulação, voltada para o socio-histórico. Indica uma ruptura com o Estruturalismo funcionalista, de inspiração saussureana.

A perspectiva interdisciplinar viceja. Há a recorrência à Psicanálise, no resgate da categoria Libido, proposta por Freud. Ela é um referente dos traços biológicos, que se esboçam nos textos freudianos em 
sua gênese teórica.

O sentido biológico convém ao empreendimento barthesiano. Fixa a inva-riância, traduzida pelo seu teor natural, de espessura atemporal. Dimensiona a onipre-sença ahistórica, materializada na tempo-ralidade histórica.

Disponibilizando o elenco dessas metalinguagens, Barthes se permite sacra-lizar o Poder, em uma anotação positiva e dialética. É a energia prazerosa, que, através do Instinto de Eros, concede nexo à vida. Sinaliza o espaço de liberdade, presente na gaiola da idealidade, como um vôo cego da visão real. Eis a sua negati-vidade, prefaciando as amarras da submissão.

Ilustra-se as relações de pertinência na categorização de Poder e da Fatalidade. Encontram-se manietados pelo reino da natureza. Possuem a idade da atempo-ralidade. Reproduzem-se na onipresença da pluralidade supra-espacial e supra-temporal, com sua fabulação libertária. Reivindicam a adesão emocional, através do olhar narcísico, fixado nos reflexos do presen-teísmo.

A Fatalidade opera, no Sistema de Significação, primário, denotado, no Significado. Está, aí, explicando, da sobreloja de sua imponência metafísica, a conflituo-sidade histórica, sincretizada pela violência física.

O Poder, em seu nexo de energia prazerosa, se pronuncia pela denotação. É a libertação do conflito histórico, onde se apagam responsabilidades. $\mathrm{O}$ sujeito histórico ganha a alforria de suas culpas e desculpas, regredindo ao engatinhamento do narcisismo primário. Tudo só pode e só deve ser explicado pela Fatalidade, o supremo Pai, que esteriliza os impasses da subjetividade humana.

Vale assinalar que o Sistema de Significação, primário, denotado, se particulariza. O Fait Divers, em suas várias manifestações, é o Significante. Denota o conflito histórico, em seu perfil de violência física, explicada pela Fatalidade, estipulando o Signo, instaurando o Poder, como expressão narcísica de irresponsabilidade histórica.

Tal Sistema de Significação transcende o perímetro da denotação. Produz a conotação. A Fatalidade, o Sujeito Absoluto, que liberta, narcisicamente, os sujeitos relativos da conflituosidade histórica - Poder - faz mais. Submete-os, pela suas irres-ponsabilidades históricas, a si, sacralização do Absoluto, e à formação social, vigente, sua determinação. Reproduz a sociedade burguesa, naturalizando-a, eternizando-a. Eis o Mito.

O Mito é uma forma de fala, que explora a conotação, grifa Barthes (1993). Não nega as coisas, porém as torna inocentes, despolitizadas. Possui um caráter imperativo e interpelatório. A sua função é a naturalização e a eternização da sociedade burguesa.

À primeira vista, a nomeação sociedade burguesa parece e aparece fora de lugar. Possui a pose de ter monopolizado, com seu dorso privativista, a produção mítica, como reprodução da realidade da infra-estrutura. É o que pode encher os olhos dos incautos.

A "sociedade burguesa" pisa no palco, com um papel específico. É um recorte, empreendido por Barthes, dando especi-ficidade para o objeto. Refere um agencia-mento de cientificidade, praticado nos limites e nas possibilidades da categorização do Mito.

No intertexto barthesiano, a concepção de Mito jorra de duas fontes episte-mológicas diversas e antagônicas. Institui-se como uma representação coletiva, de acordo com lastro de Durkheim, mas distorcida, conforme o conceito particular de Ideologia, sancionado por Marx.

Há, nessa simbiose, a postulação interdisciplinar, que retira a Semiologia do confinamento funcionalista. Reveste o Estruturalismo, de uma abordagem dialética, que se legenda como translingüística, querendo ver o horizonte dos signos no planalto e na planície dos olhares sociológicos. Faltou a Barthes explicitar, em Mitologias, essas influências e justificar as suas convergências em suas divergências episte-mológicas.

A influência marxista oferta outro desdobramento. Mesmo que o semiólogo, na sua teorização, pluralize o uso de Mito e Ideologia, ambos são sinônimos. Realizam- 
se na produção da conotação, objetivando a naturalização e a eternização da sociedade burguesa.

No Mito, vale reiterar, o trinômio Significante (Fait Divers), Significado (conflito - violência física, explicada pela Fatalidade) e o Signo, como resultante - Sistema de Significação, primário, denotativo - que se transforma. Converte-se em Signi-ficante da conotação - submissão à Fatalidade e à sociedade burguesa - gerando um outro Signo, ou seja, constituindo o Sistema de Significação, segundo, conotado.

\section{Aqui, Agora}

O SBT, do empresário Ślvio Santos, foi inaugurado em 1981. Originou-se da falência da Rede Tupi de Televisão, cujo o espólio sofreu divisão em uma concorrência pública, feita pelo governo do general João Figueiredo.

Há uma trajetória ascensional, singular, na história da Televisão brasileira. $\mathrm{O}$ camelô, Senor Abravanel, se tornou o empresário Sílvio Santos, fruto do seu mérito pessoal e de sua empatia com o status quo, sobretudo com os governos militares. Antes de formar o SBT, ele atuou na Globo e Tupi. Depois, inaugurou, em 1976, a TV Stúdio, no Rio de Janeiro, que originou o SBT.

O Programa Sílvio Santos estabeleceu o paradigma conceitual e estético da rede. Designou a sua estrutura de linguagem, habilitada a interpelar as classes, sobretudo, " $\mathrm{C}$ ", " $\mathrm{D}$ " $\mathrm{e}$ " $\mathrm{E}$ ", órfãs do modelo econômico nacional, admirável pela sua capacidade de concentração de renda.

O telejornal, Aqui, Agora, foi lançado em 1991. Autodenominou-se pelos bordões: "Arma do Povo" e "Um Jornal vibrante, que mostra, na tevê, a vida como ela é". Chegou a alcançar 31 pontos de Ibope, em 1992, em São Paulo. Teve, no ano seguinte, duas edições diárias, de segunda a sábado. Não conseguiu reprisar o seu êxito de audiência em faturamento publicitário. Foi tirado do ar no primeiro semestre de 1997; voltou no se- gundo semestre, com a ancoragem de Ney Gonçalves Dias, mas não durou seis meses.

Squirra (1993:142-143) observa que o Aqui, Agora trouxe o jornalismo popular do Rádio para a Televisão. Foi uma "cópia do Nuevediário, da Televisão argentina", porém inovou, com o uso do plano-seqüência - a gravação ininterrupta do fato, evitando a edição.

O SBT encomendou, em 1992, uma pesquisa qualitativa à empresa de consultoria Retrato. Desejava saber a opinião dos telespectadores sobre o telejornal. A Revista Veja (1992:99) publicou uma síntese dos resultados principais:

- O telejornal não é comprometido com os segmentos de maior poder político e econômico;

- O telejornal não oculta, engana ou desfoca a realidade;

- O estilo violento e sensacionalista do Aqui, Agora desperta interesse, pois evita subterfúgios;

- Para muitos telespectadores, a abordagem violenta da reportagem tem uma função educativa. Ela é um reflexo do que acontece nas ruas e, nesse sentido, orienta o público a lidar com a crescente onda de criminalidade;

- Muitos telespectadores se divertem, com os recursos sensacionalistas do telejornal, tornando-o, ainda, mais atraente. De quebra, serve de atenuante à própria violência, revelada pelo conteúdo da reportagem.

Os fragmentos conclusivos, coletados na pauta da generalidade, foram indiciais. Revelaram que os telespectadores são parte, porém não são a desculpa, como anotam Adorno e Horkheimer (1987), para a Televisão. Aludiram, também, a atualidade da tese de Maquiavel (1993), que, ao vulgo, bastam as aparências.

Os entrevistados justificaram, em síntese, as suas preferências pelo telejornal. Foi, na essência, uma autojustificativa, para as suas próprias condições de telespec-tadores. Sustentaram o seu reconhecimento às suas relações, mantidas com o Aqui, Agora.

Logo, verificou-se que o telejornal, em 
sua proposta de linguagem, foi compatível com o seu público-alvo, de breve bagagem informativa. Interpelou as vítimas do modelo econômico nacional, com o sensacionalismo, pronunciado pela conflituosidade quotidiana, urbana, sobretudo, através da crueza da violência física, em suas plurais expressões.

\section{Alusões do Imaginário}

Foi possível constatar a invariância do Fait Divers, em suas diferentes manifestações, como Significante. Estabeleceu a tipologia informativa e a organização das factualidades jornalísticas ao longo das nove edições do Aqui, Agora.

No curso da análise, evidenciou-se uma particularidade. Uma factualidade jornalística pode pluralizar vários tipos e subtipos, ao mesmo tempo, de Fait Divers. Essa noção de incerteza afirma a certeza da caracterização do Fait Divers. Basta, para tanto, interpretá-lo, para encontrar a singularidade do tipo e do subtipo, hegemô-nicos em relação aos demais.

Morin (1984) observa que o Fait Divers não possui importância informativa, porém apresenta valor pelo seu consumo emocional. Ele sublinha que as suas vítimas, ofertadas ao sacrifício pela factualidade, substituem os seus receptores - leitores, ouvintes e telespectadores.

A observação é pertinente. Consegue avaliar o Fait Divers, em sua interpelação e consumo emocionais. Revela a sua essência catártica, mobilizada pela sua circunscrição presenteísta e pela sua tonalidade conflitiva.

Também, cabe considerar o Inconsciente, no horizonte freudiano, como a relação entre uma realidade biológica e uma cultural. Ambas agenciadoras de conflitos reprimidos em sua interatividade, estabelecida na primeira infância.

Uma das formas de comunicação do Inconsciente é a Identificação Projetiva. Ela é o mecanismo que projeta os nossos con- flitos inconscientes em qualquer realidade externa e passamos a vivê-la como se fosse nossa, por quaisquer identificações.

O Fait Divers, como Significante, denota conflitos históricos, decodificados em uma relação emocional. Está fixado no seu próprio contexto, desprezando qualquer imperatividade analítica, qualquer contexto sociohistórico. Notabiliza-se pela sua submissão presenteísta. É, na essência, narcísico.

No Aqui, Agora, o Fait Divers, na tipologia informativa e na organização das telerreportagens, significou os conflitos, como violência física. Efetivou o Poder, como a Fatalidade, libertando o homem de tal conflituosidade histórica, através da irresponsabilidade, resgatando o seu narcisismo primário. Também, fixou o Mito, como a Fatalidade, submetendo o homem, a si, e ao hegemônico social, através, da sua irresponsabilidade histórica.

A recepção encontra, no Fait Divers, conflitos históricos, presentes, públicos, objetivos e emocionais. Vive-os, como se fossem seu, através da Identificação Projetiva, que, neles, encontra similitudes formais com os seus conflitos inconscientes.

A importância da observação de Morin ocorre na relação de substituição. Não é ela que une a recepção ao Fait Divers, porém a identificação. Ambos possuem, respectivamente, conflitos inconscientes e conscientes, marcados e demarcados pela emocionalidade.

A Fatalidade, como Deus ex-Machina, sacraliza o Poder de libertar o receptor de seus conflitos inconscientes, por intermédio da irresponsabilidade narcísica. É a sua Catarse. Todavia, há a imposição à hege-monia social, via irresponsabilidade narcí-sica - o Mito - como derivação da conservação dos conflitos do Inconscientes, dados como uma construção fatalística.

Verificou-se que o Sistema de Significação do Aqui, Agora, em nove edições, apresentou o Fait Divers, em suas diferentes caracterizações, como Significante invariante. Determinou a Linguagem da tipologia 
informativa e da organização das matérias.

O SBT e os telespectadores podem sustentar que o Aqui, Agora mostrou a realidade nacional. Colocou, na cena eletrônica, a violência física, nua pelo roubo, pelo incêndio, estupro e pela morte. Eis a demonstração dos bordões autoperfilantes do telejornal: "Arma do Povo" e "Um Jornal vibrante, que mostra, na tevê, a vida como ela é."

Essa noção é serva de dois intertextos. Um é o Positivismo, que se inscreve na legitimação do reinado do Significado, pré-requisito, para a absolutização da consciência. São os meios, usados, para a reprodução social, como uma dádiva da natureza. Por isso, um ente imutável, absoluto.

O outro é a Dialética hegeliana. Representa o embate contraditório da historicidade - Tese versus Antítese. Todavia, o sintetiza, em um pára-raio ahistórico: o Absoluto, explicação unilateral, com sílabas e fonemas de Estereótipo - sentido inato, conforme Barthes (s.d.).

O Fait Divers, como Significante, em seu estilo barroco, simbiotiza o Positivismo e a Filosofia hegeliana. São o seu ver na extração de fragmentos do real - fatos - sincretizados em Sistemas de Significação, com interpelação emocional. A historicida-de é tornada ahistórica pela disponibilidade da Fatalidade, como Sujeito Absoluto.

O Aqui, Agora inaugurou a estética sensacionalista no Telejornalismo brasileiro. Assumiu o Fait Divers, como matéria-prima de sua lógica de linguagem jornalís-tica, sustentada, com idas e vindas, durante sete anos.

As variações foram muitas. Houve trocas de horários e de âncoras. Chegou a contar com duas edições diárias, de segunda a sábado. Somou audiência, superiores a 30 pontos, mas se viu, ao mesmo tempo, subtraído de patrocínio. Entretanto, manteve a invariância do Fait Divers na sua paisagem linguageira.

A notável capacidade empírica de Sílvio Santos é um dos fatores, que explica o seu êxito, e o condena a equívocos. Deu-lhe a intuição de investir no Aqui, Agora, sem lhe indicar os devidos limites. O seu sucesso de audiência o conduziu à ampliação de horário e de edições semanais. Não foi levado em conta que a sua linguagem, codificada pelo Fait Divers, poderia, com facilidade, escorregar na saturação.

Não lhe faltaram opositores. Alguns se sentiram incomodados com o strip tease do Fait Divers, à flor da pele. Não era adequada às suas poses de comunicadores "neutros", diagramados pela anatomia da informação, sem abrigar interesses. Era aludir o que estava velado pelo manto da ilusão. Não existe informação, sem a existência do código do conflito, sem as cores sensacionais, mobilizadoras da interpelação emocional.

Ainda que tenha sido copiado do Nuevediário, da Televisão argentina, o Aqui, Agora afirmou um outro formato de Telejornalismo. Sincretizou, barrocamente, o Radiojornalismo, como abordagem da realidade, em pronúncia sensacionalista, com os recursos ficcionais, próprios do Gênero Telenovela. Eis a sua Antítese, eis o Fait Divers, como Significante, de seu Sistema de Significação.

A alquimia barroca do Aqui, Agora emblematizou, com notoriedade, uma tendência da Televisão brasileira nos últimos anos do século XX. A maior oferta de canais fechados tem repercutido nos abertos, que vêm permeando, enfaticamente, com a estética sensacionalista, os seus vários gêneros.

Há diversos programas, sobretudo, na década de 90, reiterativos dessa tendência. Têm sido, entre outros, os casos de Falcão na Contramão, da Bandeirantes, 190 Urgente, da CNN, Ratinho Livre e Leão Livre, da Record, Programa da Márcia e Programa do Ratinho, do SBT.

Nesse palco teatralizante, as noves edições do Aqui, Agora encenaram o Imaginário. O seu Sistema de Significação teve, como Significante, o Fait Divers, que determinou a tipologia informativa e a organização de cada edição. Mostrou conflitos pela face plural da violência física em suas relações, hegemonicamente, sadomasoquis- 
tas. Fixou o Poder, através da Fatalidade, libertando o homem desses conflitos pela irresponsabilidade narcísica; e o Mito, através da Fatalidade, submetendo o homem, a si, e à reprodução social pela irrespon-sabilidade narcísica. Eis as alusões deste Imaginário... •

\section{Referências}

1 ADORNO, Theodor e HORKHEIMER, Max. Dialética do Esclarecimento: Fragmentos de estudos filosóficos. 2.ed. Rio de Janeiro: Jorge Zahar, 1986.

2 BARTHES, Roland. Mitologias. 9.ed. Rio de Janeiro: Bertrand Brasil, 1993.

3 BARTHES, Roland. Ensaios Críticos. Lisboa: Edições 70, 1971.

4 BARTHES, Roland. A Aula. São Paulo: Cultrix, s.d.

5 GIANNINI, Silvio. 'O Rosto da Periferia'. Revista Veja. São Paulo, 18 de novembro de 1992, p.99.

6 MAQUIAVEL, Nicolau. O Príncipe. São Paulo: Martins Fontes, 1993.

7 MORIN, Edgar. Cultura de Massas no Século XX: 0 espirito do tempo, 1 Neurose. 6.ed. Rio de Janeiro: Forense Universitária, 1984.

8 SQUIRRA, Sebastião. Boris Casoy: 0 Âncora no telejornalismo brasileiro. 2.ed. Petrópolis: Vozes, 1993. 